Check for updates

Cite this: RSC Adv., 2018, 8, 1875

Received 30th October 2017

Accepted 28th December 2017

DOI: 10.1039/c7ra11956a

rsc.li/rsc-advances

\section{Environmental factors, but not abundance and diversity of nitrifying microorganisms, explain sediment nitrification rates in Yangtze lakes $\dagger$}

\author{
Lu Yao, (D) ab Chengrong Chen, ${ }^{\mathrm{b}}$ Guihua Liu, ${ }^{\mathrm{a}}$ Feng Li ${ }^{\mathrm{c}}$ and Wenzhi Liu (DD *a
}

\begin{abstract}
Sediment nitrification plays a vital role in nitrogen (N) biogeochemical cycling and ecological function of an aquatic ecosystem. The relative importance of environmental factors and nitrifying microbial communities in regulating sediment nitrification process has received less attention, especially in aquatic habitats where high $\mathrm{N}$ loads are frequently detected. Here, we report the potential nitrification rates of 35 sediment samples from 10 shallow lakes in the Yangtze River basin. The diversity and abundance of ammonia-oxidizing archaea $(A O A)$ and bacteria $(A O B)$ were quantified using archaeal and bacterial amoA genes. The results showed that there was no significant difference in sediment nitrification rates among sites of different trophic state. The nitrification rates were positively related to water chlorophyll-a, sediment $\mathrm{N}$ and carbon levels, but not significantly associated with diversity and abundance of ammonia-oxidizing microorganisms and submerged plants. Interestingly, the abundance and diversity of sediment AOB but not $A O A$ communities were significantly influenced by trophic state. In addition, AOB communities were more sensitive to changes in local environments and catchment land uses than the AOA communities. Using path analysis, we found that $55-60 \%$ of the indirect effect of catchment land uses on nitrification rates was mediated via sediment $\mathrm{N}$ content. Our findings suggest that, although nitrification is a microbial process, variation in sediment nitrification rates in Yangtze lakes is mainly explained by abiotic factors but not by microbial abundance and diversity.
\end{abstract}

\section{Introduction}

Eutrophication has become one of the most serious environmental problems in aquatic ecosystems throughout the world, especially in China. ${ }^{1,2}$ Nitrogen $(\mathrm{N})$ is essential for synthesizing nucleic acids and proteins and can be the limiting or co-limiting nutrient for phytoplankton production in lakes and other bodies of water. ${ }^{3,4}$ However, $\mathrm{N}$ pollution has increased considerably in recent decades due to increased fertilizer use, wastewater discharge, atmospheric deposition, and $\mathrm{N}$ fixation by agricultural crops in terrestrial ecosystems. ${ }^{5}$ High $\mathrm{N}$ loading in shallow lakes is generally linked to water eutrophication and several attendant ecological problems, including water quality deterioration, toxic algal blooms, and decline of freshwater biodiversity. ${ }^{6}$

The ability and mechanism of shallow lakes to cope with excess $\mathrm{N}$ input have attracted much attention in recent

${ }^{a}$ Key Laboratory of Aquatic Botany and Watershed Ecology, Wuhan Botanical Garden, Chinese Academy of Sciences, Lumo Road No. 1, Wuchang District, Wuhan, 430074, PR China. E-mail: liuwz@wbgcas.cn; Fax: +86 27 87510251; Tel: +86 2787510987

${ }^{b}$ Australian Rivers Institute and Griffith School of Environment, Griffith University, Nathan, 4111, Australia

${ }^{c}$ Dongting Lake Station for Wetland Ecosystem Research, Institute of Subtropical Agriculture, The Chinese Academy of Sciences, Changsha 410125, PR China

$\dagger$ Electronic supplementary information (ESI) available. See DOI: 10.1039/c7ra11956a decades. ${ }^{7-9}$ The coupled nitrification-denitrification processes convert ammonium $\left(\mathrm{NH}_{4}{ }^{+}\right)$to nitrite $\left(\mathrm{NO}_{2}{ }^{-}\right)$and nitrate $\left(\mathrm{NO}_{3}{ }^{-}\right)$ via nitrification, which can then be lost to the atmosphere as $\mathrm{N}_{2}$ gas through denitrification. ${ }^{\mathbf{1 0 , 1 1}}$ In addition, the anammox process can use $\mathrm{NH}_{4}{ }^{+}$as electron donor and $\mathrm{NO}_{2}{ }^{-}$as electron acceptor to accomplish $\mathrm{N}$ removal. ${ }^{12}$ The first key step of coupled nitrification-denitrification processes, the oxidation of $\mathrm{NH}_{4}{ }^{+}$to $\mathrm{NO}_{2}{ }^{-}$, is catalyzed by ammonia monooxygenase enzyme. Archaeal and bacterial amoA genes have been frequently used as molecular markers to examine the community structure of ammonia-oxidizing archaea (AOA) and bacteria (AOB) in sediments and soils. ${ }^{\mathbf{1 3 - 1 6}}$

Microbially mediated nitrification generally occurs in the presence of oxygen in lake sediments and varies greatly across spatial and temporal scales. ${ }^{17}$ Sediment nitrification rates are strongly influenced by local water quality and sediment properties, including $\mathrm{NH}_{4}{ }^{+}$availability and organic matter., ${ }^{9,18,19}$ In addition, several studies have reported that the presence of vegetation can influence nitrification in both terrestrial and aquatic environments. ${ }^{20,21}$ Rooted submerged macrophytes can impact sediment nitrification by altering the organic carbon (C) inputs from root excretion, by competing with nitrification for $\mathrm{NH}_{4}{ }^{+}$and by regulating the oxygen and redox status in the rhizosphere. ${ }^{22}$ Recently, many studies have examined the relationships between nitrifying microbial communities and 
sediment nitrification rates, but their results are not consistent. ${ }^{\mathbf{1 4 2 3 - 2 6}}$ Hou et al. (2013) reported that sediment potential nitrification rates were positively related to AOB abundance in two large eutrophic lakes in China. ${ }^{25}$ Wankel et al. (2011) found no significant correlation between sediment nitrification rates and the abundance of AOA and AOB in an estuary, U.S.A. ${ }^{\mathbf{1 4}}$

Catchment land uses can reflect the degree of anthropogenic activities, such as agricultural expansion and urban development. ${ }^{27}$ It has been shown that catchment land uses may significantly affect both local environmental factors and biological communities in aquatic habitats ${ }^{28}$ which in turn can impact sediment nitrification processes. Arango and Tank ${ }^{29}$ have reported that sediment nitrification rates in Michigan headwater streams increase with increasing agriculture in catchment. Such a positive association is possible due to the fact that agricultural streams generally have high sediment $\mathrm{C}$ content, which is positively related to nitrification rates. ${ }^{29}$ Although several works have examined the correlations between land use and sediment nitrification, ${ }^{30}$ none have revealed the mechanisms by which catchment land uses indirectly influence the nitrification process of aquatic ecosystems.

In the Yangtze River basin there are 648 natural lakes with an area larger than $1 \mathrm{~km}^{2} .{ }^{31}$ Most of Yangtze lakes are shallow (mean depth $<5 \mathrm{~m}$ ) and mostly located in the middle and lower Yangtze River basin. These shallow lakes play a vital role in providing fresh water for various purposes (human consumption, agricultural and industrial use) and developing aquaculture and tourism. However, due to rapid economic development and uncontrolled discharge of pollutants in catchments, most of the lakes in the Yangtze River basin have faced many environmental problems, including water eutrophication, harmful algal blooms, heavy metal pollution and degradation of submerged vegetation. ${ }^{31}$ It has been reported that the percent of eutrophic and hypereutrophic lakes has increased from approximately $41 \%$ in 1980 s to nearly $85 \%$ in 2005 in China. ${ }^{2}$

In this study, a total of 35 sediment samples were collected from 10 shallow lakes in the Yangtze River basin. We measured the sediment potential nitrification rates and quantified the diversity and abundance of nitrifying microbes. The objectives of our study were (1) to compare sediment potential nitrification rates and nitrifying microorganisms among site types; (2) to examine the relationships between nitrification rates and abiotic factors (water quality and sediment properties) and biotic factors (nitrifying microorganisms and submerged vegetation); and (3) to explore the possible indirect effect of catchment land uses on sediment nitrification rates. Two hypotheses were tested: (1) both local abiotic and biotic factors would significantly impact sediment nitrification; and (2) catchment agriculture and urban would alter the sediment nitrification in lakes mainly through their effects on sediment properties.

\section{Material and methods}

\subsection{Site description and field sampling}

In July 2013, 10 lakes located in the middle and lower Yangtze River basin were chosen randomly (Fig. 1). All selected lakes are shallow and have a mean water depth less than $4 \mathrm{~m}$. The

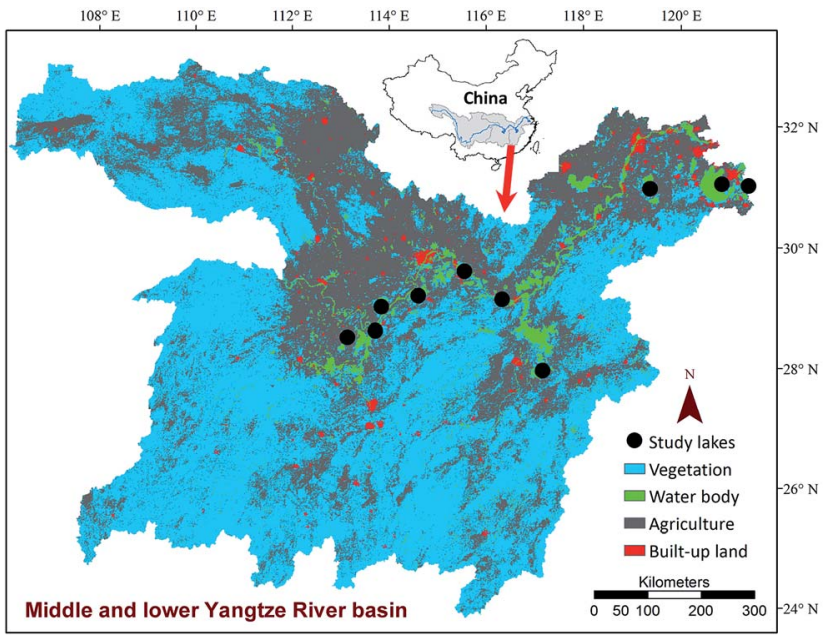

Fig. 1 Location of 10 study lakes in the Yangtze River basin, China.

smallest lake is Lake Cihu with an area of $8.15 \mathrm{~km}^{2}$ and the largest lake is Lake Taihu with an area of $2338 \mathrm{~km}^{2}$. Three to four sampling sites were selected along one transect at regular intervals from the littoral areas to lake centre in each lake. Littoral sites were in general located at water depth less than 2 $\mathrm{m}$, approximately 100-200 $\mathrm{m}$ away from the lake shore. ${ }^{6}$ At each site, replicate surface sediments were randomly collected within an area about $20 \mathrm{~m}^{2}$ using a home-made grab sampler and the top $2 \mathrm{~cm}$ of sediment was mixed and homogenized to form a composite sample. If submerged vegetation was present in a sampling site, rhizosphere sediments were collected by shaking off sediments that were loosely adhering to the plant roots.

Approximately $500 \mathrm{~g}$ sediments from each site were put into plastic bags and stored in anoxic conditions at $5{ }^{\circ} \mathrm{C}$ in a portable refrigerator. Moreover, about $10 \mathrm{~g}$ sediments were collected in a centrifuge tube and immediately frozen in liquid $\mathrm{N}_{2}$. Before sediment sampling, a $500 \mathrm{~mL}$ bottom water sample was collected at about $1 \mathrm{~m}$ above the sediments at each sampling site. In addition, submerged plant communities were investigated using a plant grab $(25 \times 35 \mathrm{~cm})$ with three replicates. Species richness, reflecting the $\alpha$-diversity of submerged vegetation, was defined as the species number recorded in each sampling site. The fresh biomass of submerged vegetation per square meter was calculated after rinsing the plants with lake water.

\subsection{Measurements of potential nitrification rates}

The potential nitrification rates of lake sediments were measured in triplicate for each site by the shaken slurry method as modified by Hou et al. ${ }^{25}$ This method provided an upperbound estimate of in situ nitrification under the conditions of aeration, unlimited $\mathrm{NH}_{4}{ }^{+}$and phosphorus. Approximately $10 \mathrm{~g}$ of fresh sediments from each sampling site were weighed into $250 \mathrm{~mL}$ brown glass bottles and mixed with $100 \mathrm{~mL}$ of phosphate buffer ( $1 \mathrm{mM}, \mathrm{pH} 7.4)$ and $0.5 \mathrm{~mL}$ of $\left(\mathrm{NH}_{4}\right)_{2} \mathrm{SO}_{4}(0.25 \mathrm{M})$. All bottles were then incubated on a horizontal shaker (200 
$\mathrm{rpm})$ at room temperature for $24 \mathrm{~h}$. At five time intervals $(1,4$, 10, 16 and 24 hours), $5 \mathrm{~mL}$ samples were collected from the slurry, centrifuged for $5 \mathrm{~min}$ at $2800 \mathrm{rpm}$ and filtered through $0.45 \mu \mathrm{m}$ membrane filters. Concentrations of $\mathrm{NH}_{4}{ }^{+}$and $\mathrm{NO}_{3}{ }^{-}$in the filtrate were measured using an automatic nutrient analyser (EasyChem plus, Systea, Italy). The potential nitrification rates were calculated from the change in $\mathrm{NO}_{3}{ }^{-}$concentration during incubation using linear regression, and data were reported in ng $\mathrm{NO}_{3}{ }^{-}-\mathrm{N} \mathrm{g}^{-1} \mathrm{~h}^{-1}$.

\subsection{Measurements of nitrifying community diversity and abundance}

DNA was extracted from $0.5 \mathrm{~g}$ sediment using the PowerSoil DNA Isolation Kit (MoBio Laboratories, CA, USA). The primer sets Arch-amoAF/Arch-amoAR and amoA-1F/amoA-2R were used for the amplification of the archaeal and bacterial $a m o A$ genes, respectively. ${ }^{32,33}$ Each reaction was performed in a $25 \mu \mathrm{L}$ volume consisting of $1 \mu \mathrm{L}$ of DNA template (10-100 ng $\left.\mu \mathrm{L}^{-1}\right), 0.5 \mu \mathrm{L}$ of each primer $(10 \mathrm{mM}), 0.2 \mu \mathrm{L}$ of rTaq polymerase $\left(5 \mathrm{U} \mu \mathrm{L}^{-1}\right), 0.5$ $\mu \mathrm{L}$ of deoxynucleotide triphosphates $(10 \mathrm{mM})$ and $2.5 \mu \mathrm{L}$ of $10 \times$ buffer. The primers and thermal cycling profiles were adapted from Li et $a l .{ }^{13}$ The amplified PCR products were gel purified (Axygen Biosciences, Union City, USA) and cloned into the pMD18-T vector (TaKaRa, DaLian, China), which was subsequently transferred into Trans-5 $\alpha$ competent cells (Transgen Biotech, Beijing, China). Sixty randomly selected clones per sample for each gene were sequenced using an ABI-3730XL (Applied BioSystems, USA). The sequences with more than 95\% similarity were classified into operational taxonomic units (OTUs) using the Mothur software by the furthest neighbor algorithm. The diversity indices (i.e., Chao1, Shannon and Simpson) were calculated for each sediment sample using the software Mothur. The archaeal and bacterial amoA sequences have been deposited in the GenBank with the following accession numbers: KY244149-KY244154 and KY244243-KY244299 for archaeal amoA and KY244155-KY244242 for bacterial amoA.

Quantitative PCR (qPCR) was used to determine the abundance (i.e., copy number) of archaeal and bacterial amoA genes in sediments. The qPCR was performed on an ABI Prism 7900 Sequence Detection System (Applied Biosystems, CA, USA) with the SYBR green Master Mix (Takara, Dalian, China). Primer sets of Arch-amoAF/Arch-amoAR and amoA-1F/amoA-2R were applied for the archaeal and bacterial amoA genes, respectively. The 25 $\mu \mathrm{L}$ qPCR mixture contained $10 \mu \mathrm{L}$ of SYBR green qPCR Master Mix, $1 \mu \mathrm{L}$ of each primer $(10 \mu \mathrm{M})$ and $2 \mu \mathrm{L}$ of DNA template. Standard curves were constructed with serial plasmid dilutions of a known amount of plasmid DNA involving the archaeal and bacterial amoA genes. The AOA and AOB abundance was estimated based on the constructed standard curve, and converted into copies per gram of sediment.

\subsection{Measurements of local abiotic factors and catchment land use}

Water depth and secchi depth (SD) were measured in field at each sampling site. Concentrations of total organic C (TOC) and total $\mathrm{N}(\mathrm{TN})$ in water samples were determined using an elemental analyzer (Vario TOC cube, Elementar, Germany). Total phosphorus (TP) concentration was analyzed using the colorimetric method on a spectrophotometer (PerkinElmer, Inc., Waltham, USA). Chlorophyll-a (Chl-a) content was determined by filtration through $0.45 \mu \mathrm{m}$ membrane filters followed by extraction with $90 \%$ acetone and fluorometry. The trophic state index (TSI) was calculated based on the water SD, TP and Chl-a concentrations. ${ }^{34}$ TSI ranges $<30,30-50,50-70$ and $>70$ respectively indicated oligotrophic, mesotrophic, eutrophic and hypereutrophic state. ${ }^{2}$ Therefore, the 35 sampling sites could be classified into mesotrophic sites $(N=6)$, eutrophic sites $(N=$ $21)$ and hypertrophic sites $(N=8)$. Sediment moisture was determined by oven drying $50 \mathrm{~g}$ sediments at $105{ }^{\circ} \mathrm{C}$ for $48 \mathrm{~h}$, while sediment density was analyzed by weighing $50 \mathrm{~cm}^{3}$ sediments after drying overnight at $105{ }^{\circ} \mathrm{C}$. Sediment total C (STC) and total $\mathrm{N}$ (STN) contents of air-dried sediments were measured using an elemental analyzer (Vario TOC cube, Elementar, Germany). Concentrations of sediment $\mathrm{NH}_{4}{ }^{+}$and $\mathrm{NO}_{3}{ }^{-}$ were measured by extracting $10 \mathrm{~g}$ of fresh sediments with $100 \mathrm{~mL}$ of $2 \mathrm{M} \mathrm{KCl}$ for 1 hour and using an automatic nutrient analyser (EasyChem plus, Systea, Italy).

To determine the land use characteristics of lake catchments, we first extracted the catchment boundaries of the 10 study lakes by a $1 \mathrm{~km}$ resolution digital elevation model (DEM). We obtained the land use/land cover map (GlobeLand30) of the Yangtze River basin from the National Geomatics Center of China. ${ }^{35}$ This map has a $30 \mathrm{~m}$ resolution and describes the spatial distribution of 10 land use types based on Landsat TM and HJ-1-CCD images in 2010. The original land use types were grouped into four main classes: (1) agriculture; (2) built-up land, including urban, rural settlements and industrial areas; (3) vegetation, including forest, grassland and shrubland; and (4) water body, including lakes and other aquatic habitats. The area and percentage of four land use classes in a lake catchment were calculated in software ArcGIS 10.0 using the overlay function on the reclassified land use map and the catchment boundaries.

\subsection{Statistical analyses}

We checked the data for normal distribution using the ShapiroWilk test before statistical analyses. Non-normally distributed data were square root (Sqrt) and natural $\log (\mathrm{Ln})$ transformed to reach a normal distribution when possible. One-way ANOVA followed by Tukey post-hoc tests was used to determine the differences in nitrification rates, nitrifying communities, water quality, sediment properties and submerged vegetation among sites of different trophic status. The relationships among nitrification rates, nitrifying communities, local factors and catchment land uses were assessed by the Pearson correlation and simple regression analyses. All above statistical analyses were conducted by the software PASW 19.0 (IBM SPSS Inc., Chicago, USA).

The path analysis was employed to determine the indirect effect of catchment land uses on sediment nitrification rates. Firstly, we constructed a conceptual model linking catchment land use and local factors to nitrification rates based on the 
existing literature and ecological principles (Fig. S1 $\dagger$ ). Secondly, according to the results of Pearson correlation and regression analyses, promising explanatory variables were chosen to include in path analysis. Finally, the path coefficients, $R^{2}$, direct and indirect effects, and model fit parameters were determined using software AMOS 20.0 (Amos Development Corporation, Chicago, USA) with the maximum likelihood estimation method. The chi-square $\left(\chi^{2}\right)$ test and comparative fit index (CFI) were used to evaluate the overall fit of the final path models. An insignificant $\chi^{2}$ statistic $(P>0.05)$ and CFI value $>0.9$ indicated that the final path models provide a reasonable fit. ${ }^{6}$

\section{Results}

\subsection{Water quality, sediment properties and submerged vegetation}

The TOC content in water varied between 3.67 and $10.93 \mathrm{mg} \mathrm{L}^{-1}$, with a mean value of $6.64 \pm 1.48 \mathrm{mg} \mathrm{L}^{-1}$ (Table $\mathrm{S} 1 \dagger)$. The highest concentrations of water $\mathrm{TN}\left(2.13 \mathrm{mg} \mathrm{L}^{-1}\right)$ and TP $\left(0.51 \mathrm{mg} \mathrm{L}^{-1}\right)$ were found in Lake Dianshanhu and Lake Donghu, respectively (Table $\mathrm{S} 1 \dagger$ ). The Chl-a concentration ranged from a minimum value of 1.38 to a maximum value of $78.77 \mathrm{mg} \mathrm{m}^{-3}$. The averaged STC and STN contents were 28.22 \pm 22.65 and $2.18 \pm 1.35 \mathrm{mg} \mathrm{g}^{-1}$, respectively. Submerged plants were detected in 20 sampling sites, with the greatest species richness of 7 and largest fresh biomass of $2640 \mathrm{~g} \mathrm{~m}^{-2}$ (Table S1†).

The water column TP, Chl-a concentrations and TSI in hypertrophic sites were significantly greater than those in mesotrophic and eutrophic lake sites, while the water SD was considerably lower in hypertrophic sites compared to other sites (Table 1). The maximum species richness and biomass of submerged plants were found in mesotrophic sites (Table 1). There are no submerged macrophytes in hypertrophic sites. Catchment agriculture showed a positive correlation with water TOC and TN concentrations (Table S2 $\dagger$ ). Catchment built-up land was positively related to water $\mathrm{TN}$ contents but negatively associated with STC and STN.

\subsection{Diversity and abundance of nitrifying community}

The Shannon index of AOA ranged between 0.20 and 2.58, while the Shannon index of AOB varied from 0.41 to 2.66 (Table S3 $\dagger$ ). The abundance of AOA in lake sediments ranged from $0.02 \times$ $10^{4}$ to $333.34 \times 10^{4}$ gene copies per $\mathrm{g}$ sediment, while the abundance of the AOB varied between $0.17 \times 10^{4}$ and $10.37 \times$ $10^{4}$ gene copies per $g$ sediment (Table $\mathrm{S} 3 \dagger$ ). The abundance and diversity of sediment AOB but not AOA were significantly different among sites of different trophic status (Table 2). Interestingly, the lowest AOB diversity and abundance were generally found in eutrophic sites.

Compared with AOA communities, AOB communities were more sensitive to changes in local environments (Table 3). Among the diversity indices and abundance of AOA, only abundance had a significant relationship with local water quality and sediment properties (Table 3). In contrast, the Shannon and Simpson indices of AOB showed a significant correlation with TOC and Chl-a concentration. In addition, the abundance of AOB was positively associated with Chl-a and TSI, but negatively correlated with and SD (Table 3 ).

\subsection{Sediment potential nitrification rates}

Sediment potential nitrification rates ranged between 15.7 and $876.4 \mathrm{ng} \mathrm{NO}{ }_{3}^{-}-\mathrm{N} \mathrm{g}^{-1} \mathrm{~h}^{-1}$, with a mean value of $192.7 \mathrm{ng} \mathrm{NO}_{3}{ }^{-}$ $\mathrm{N} \mathrm{g}^{-1} \mathrm{~h}^{-1}$ (Table $\left.\mathrm{S} 3 \dagger\right)$. Sediment potential nitrification rates in

Table 1 Water quality, sediment properties and submerged vegetation characteristics (mean \pm standard deviation) among site types in lakes ${ }^{a}$

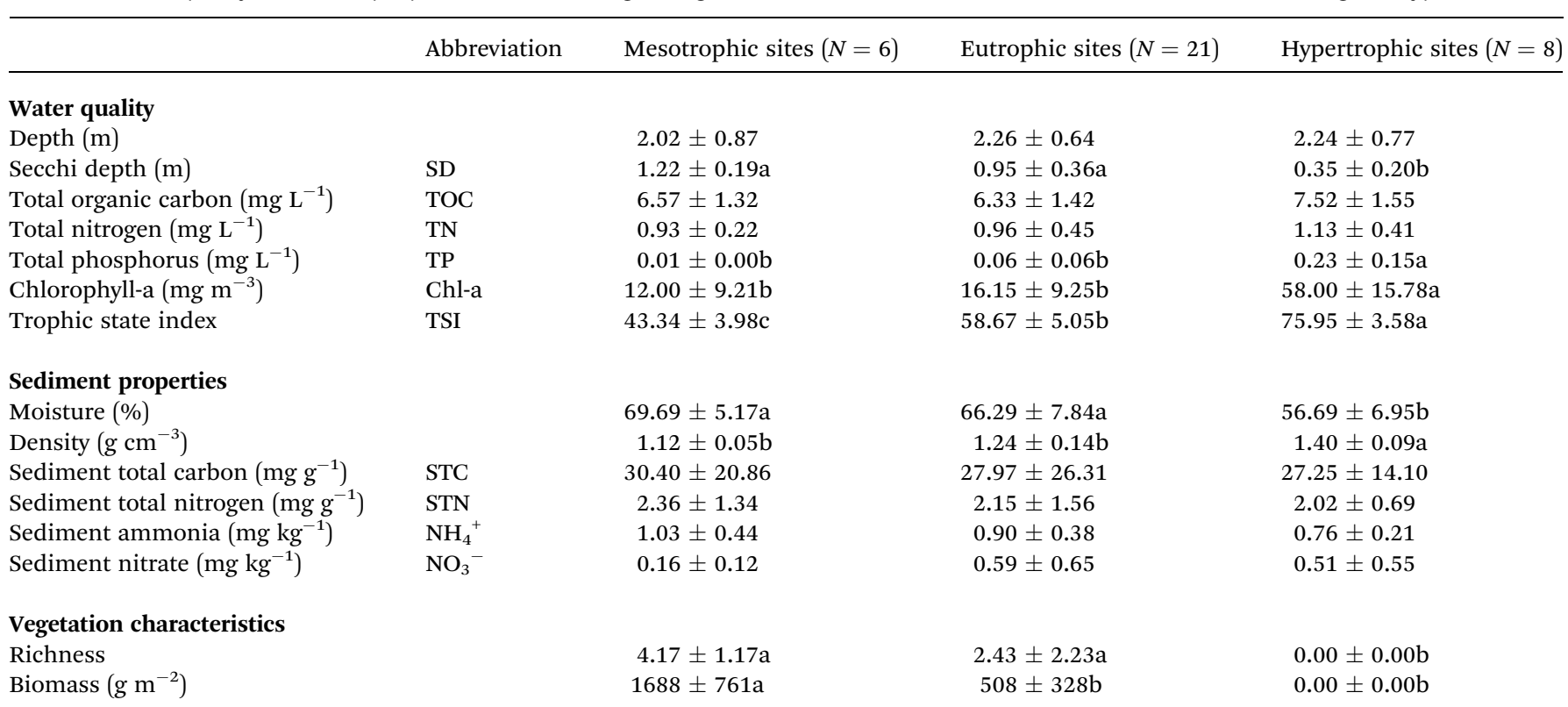

${ }^{a}$ Mean \pm standard deviation followed by different lowercase letters indicates significant difference $(P<0.05)$ among site types. 
Table 2 Diversity and abundance (mean \pm standard deviation) of sediment nitrifying communities among site types in lakes ${ }^{a}$

\begin{tabular}{lllc}
\hline & $\begin{array}{l}\text { Mesotrophic } \\
\text { sites }(N=6)\end{array}$ & $\begin{array}{l}\text { Eutrophic sites } \\
(N=21)\end{array}$ & $\begin{array}{l}\text { Hypertrophic } \\
\text { sites }(N=8)\end{array}$ \\
\hline Chao1 index & & & \\
AOA & $11.40 \pm 8.53$ & $10.94 \pm 9.29$ & $5.63 \pm 2.49$ \\
AOB & $27.33 \pm 12.89 \mathrm{a}$ & $14.82 \pm 9.72 \mathrm{~b}$ & $27.38 \pm 18.76 \mathrm{a}$ \\
& & & \\
Shannon index & & & \\
AOA & $1.14 \pm 1.00$ & $1.36 \pm 0.53$ & $0.87 \pm 0.50$ \\
AOB & $2.02 \pm 0.67 \mathrm{a}$ & $1.10 \pm 0.50 \mathrm{~b}$ & $1.98 \pm 0.56 \mathrm{a}$ \\
\multicolumn{1}{l}{ Simpson index } & & & \\
AOA & $0.53 \pm 0.37$ & $0.35 \pm 0.19$ & $0.56 \pm 0.26$ \\
AOB & $0.25 \pm 0.22 \mathrm{~b}$ & $0.51 \pm 0.19 \mathrm{a}$ & $0.21 \pm 0.15 \mathrm{~b}$
\end{tabular}

Abundance

$\begin{array}{lllr}\text { AOA } & 1.73 \pm 1.33 & 1.33 \pm 1.20 & 53.96 \pm 115.68 \\ \text { AOB } & 1.33 \pm 1.10 \mathrm{~b} & 0.56 \pm 0.28 \mathrm{~b} & 3.50 \pm 3.30 \mathrm{a}\end{array}$

Abundance ratio

$\begin{array}{llll}\mathrm{AOA} / \mathrm{AOB} & 2.12 \pm 1.75 & 2.81 \pm 3.49 & 7.64 \pm 11.07\end{array}$

${ }^{a}$ Mean \pm standard deviation followed by different lowercase letters indicates significant difference $(P<0.05)$ among site types.

hypertrophic sites $\left(239.8 \pm 75.9 \mathrm{ng} \mathrm{NO}_{3}{ }^{-}-\mathrm{N} \mathrm{g}^{-1} \mathrm{~h}^{-1}\right)$ were slightly but not significantly higher than those in eutrophic sites $\left(185.4 \pm 201.1 \mathrm{ng} \mathrm{NO}_{3}{ }^{-}-\mathrm{N} \mathrm{g}^{-1} \mathrm{~h}^{-1}\right)$ and mesotrophic sites $\left(155.5 \pm 215.4 \mathrm{ng} \mathrm{NO}{ }_{3}^{-}-\mathrm{N} \mathrm{g}^{-1} \mathrm{~h}^{-1}\right.$; Fig. 2). The potential nitrification rate showed positive relationships with Chl-a $\left(R^{2}=\right.$ $0.15, P=0.026)$, STC $\left(R^{2}=0.17, P=0.015\right)$ and STN $\left(R^{2}=0.33, P\right.$ $<0.001$; Fig. 3). However, the nitrification rate had no

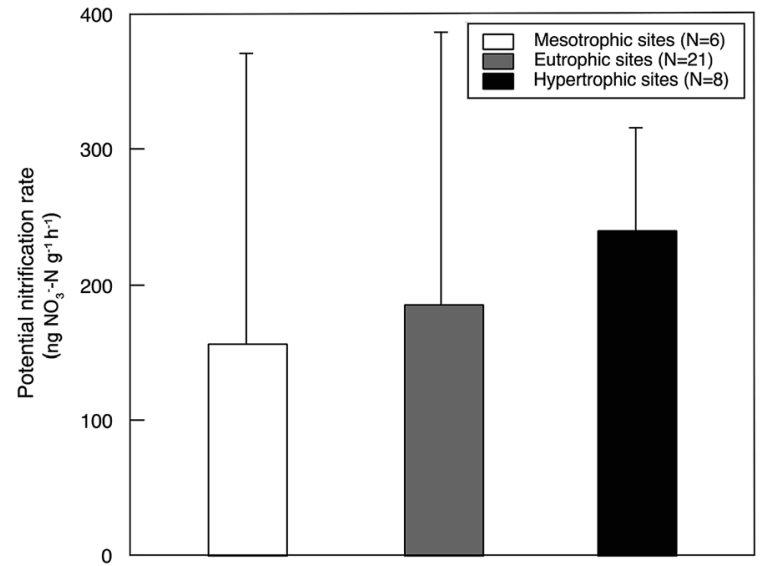

Fig. 2 Sediment potential nitrification rate (mean \pm standard deviation) among site types in lakes.

significant relationship with submerged vegetation characteristics. Furthermore, there was no significant correlation between potential nitrification rates and nitrifying community structure (Fig. S2 $\dagger$ ).

The CFI values for the three path models in Fig. 4 were 0.970 , 0.918 and 0.932 , respectively, indicating that these path models were acceptable. As we hypothesized, catchment land uses indirectly affected the sediment potential nitrification in lakes mainly through their effects on sediment properties (Fig. 4). Over half of the indirect effect (58.3\%) of catchment agriculture on potential nitrification was mediated via STN (Table 4). Similarly, approximately $55.0 \%$ and $41.8 \%$ of the indirect effects of catchment built-up land on potential nitrification were mediated via STN and STC, especially (Table 4).

Table 3 Pearson correlation coefficients between nitrifying communities and local factors and catchment land uses $(N=35)$

\begin{tabular}{|c|c|c|c|c|c|c|c|c|c|}
\hline & Chao1 & Shannon & Simpson & Abundance & Chao1 & Shannon & Simpson & Abundance & $\begin{array}{l}\mathrm{AOA} / \mathrm{AOB} \\
\begin{array}{l}\text { Abundance } \\
\text { ratio }\end{array}\end{array}$ \\
\hline Depth & 0.14 & 0.26 & -0.28 & -0.04 & -0.08 & -0.12 & 0.13 & -0.02 & -0.13 \\
\hline SD & -0.02 & -0.01 & 0.01 & $-0.34^{a}$ & -0.15 & -0.27 & 0.25 & $-0.44^{b}$ & -0.31 \\
\hline TOC & -0.34 & -0.29 & 0.28 & 0.14 & $0.46^{b}$ & $0.46^{b}$ & $-0.49^{b}$ & 0.29 & -0.04 \\
\hline Chl-a & -0.08 & -0.02 & 0.03 & $0.43^{a}$ & 0.28 & $0.39^{a}$ & $-0.37^{a}$ & $0.60^{b}$ & $0.35^{a}$ \\
\hline TSI & -0.14 & -0.11 & 0.07 & 0.32 & 0.05 & 0.12 & -0.16 & $0.39^{a}$ & 0.27 \\
\hline Moisture & 0.03 & 0.22 & -0.26 & -0.19 & -0.11 & -0.18 & 0.16 & -0.23 & -0.11 \\
\hline Density & -0.05 & -0.07 & 0.08 & 0.11 & -0.09 & -0.02 & 0.02 & 0.15 & 0.09 \\
\hline STC & -0.29 & -0.29 & 0.28 & -0.01 & 0.10 & 0.05 & -0.08 & 0.09 & -0.11 \\
\hline STN & -0.12 & -0.14 & 0.12 & -0.07 & 0.00 & -0.09 & 0.10 & -0.08 & -0.11 \\
\hline Catchment agriculture & -0.23 & -0.35 & $0.38^{a}$ & -0.18 & $0.39^{a}$ & $0.44^{b}$ & $-0.49^{b}$ & 0.09 & -0.33 \\
\hline Catchment built-up land & 0.01 & -0.02 & 0.01 & 0.10 & 0.02 & 0.03 & -0.01 & -0.04 & 0.24 \\
\hline Catchment vegetation & 0.22 & $0.36^{a}$ & $-0.36^{a}$ & -0.08 & $-0.33^{a}$ & $-0.37^{a}$ & $0.33^{a}$ & -0.17 & -0.01 \\
\hline
\end{tabular}

${ }^{a} P<0.05 .{ }^{b} P<0.01$; see Table 1 for the abbreviations. 

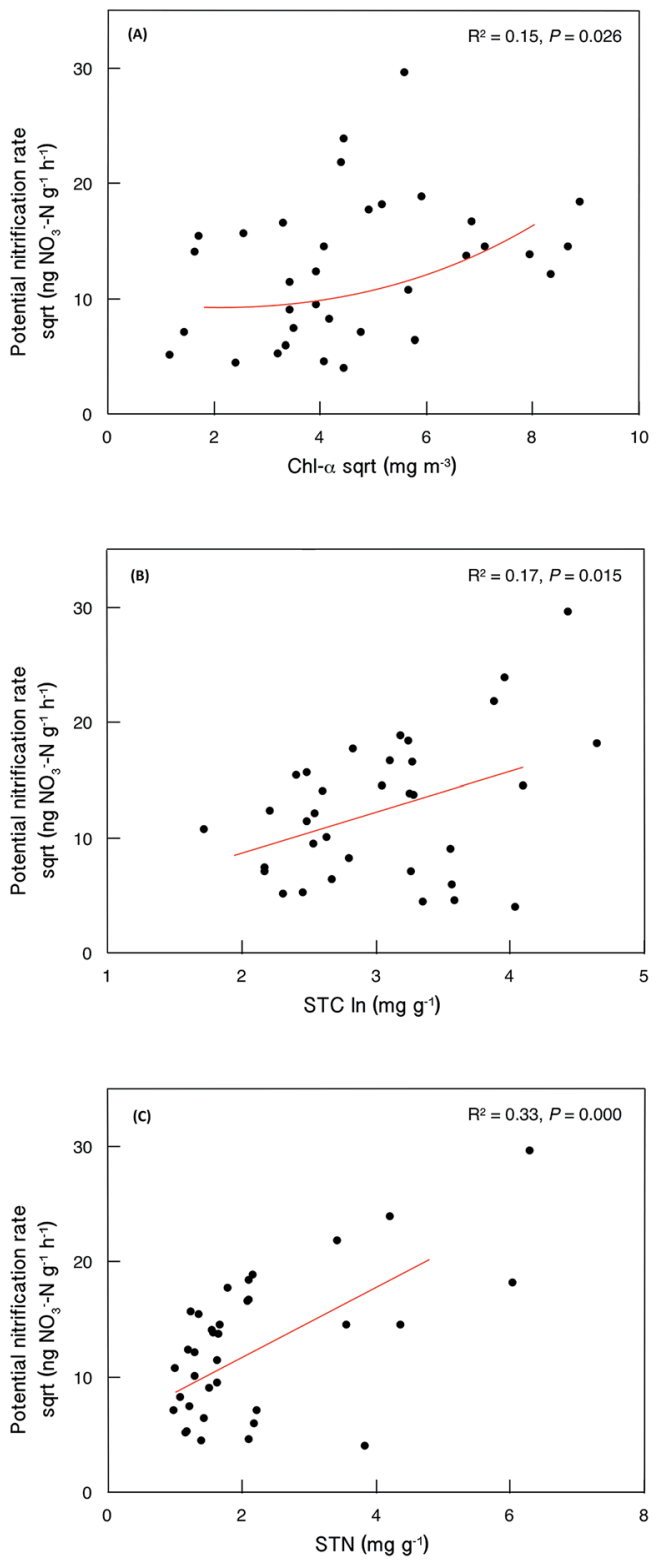

Fig. 3 Relationships between sediment potential nitrification rate and selected local abiotic factors $(N=35)$.

\section{Discussion}

\subsection{Influences of multi-scale abiotic factors on sediment nitrification}

Contrary to our first hypothesis, we found that the spatial variation of sediment nitrification rates in Yangtze lakes could be mainly due to changes in water quality and sediment properties rather than submerged vegetation and microbial abundances (Fig. 3). The effects of local environmental factors on sediment potential nitrification have been frequently investigated in previous studies.,.$^{9,15,18,19}$ In the present study, we found that STN, STC and Chl-a were the main factors affecting the sediment nitrification rates in Yangtze lakes. Although nitrification rates have been positively correlated with $\mathrm{NH}_{4}{ }^{+}$availability in a variety of habitats, ${ }^{18,36}$ such a positive relationship
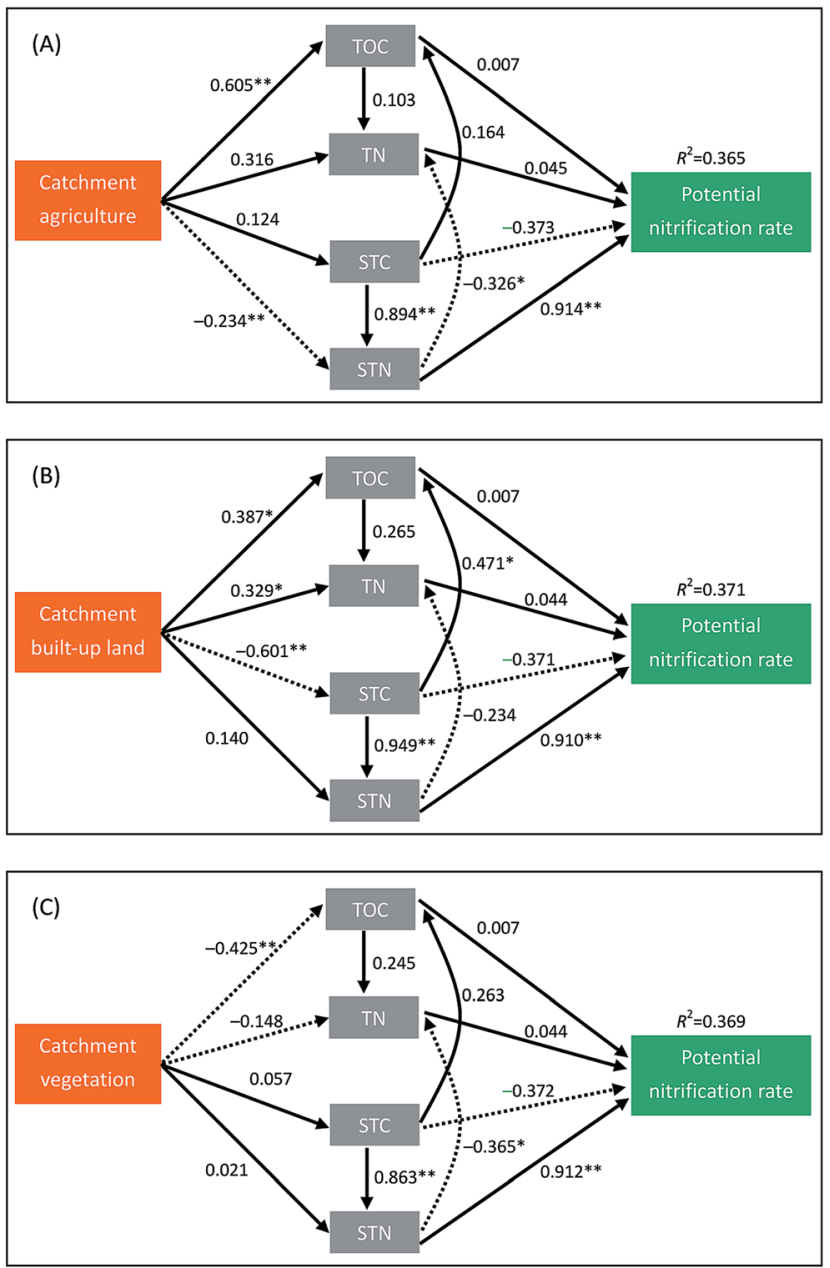

Fig. 4 Structural equation models depicting the indirect effects of catchment agriculture (A), built-up land (B) and vegetation (C) on the sediment potential nitrification rate. Chl-a is not included in the final path models, because no evidence exists for a direct influence of Chla on sediment nitrification. Solid and dashed lines indicate positive and negative effects, respectively. Numbers adjacent to the lines are standardized path coefficients. *indicates $P<0.05$, **indicates $P<$ 0.01 . The $R^{2}$ values above the nitrification rate boxes represent the total variance explained by the models.

was not detected in our study. Instead, we found that STN was positively associated with sediment potential nitrification. This relationship has been frequently reported and may suggest that sediment nitrification is closely tied to rate of $\mathrm{N}$ mineralization from sediment organic matter. ${ }^{37,38}$ Many studies have examined the effect of sediment $\mathrm{C}$ availability on nitrification rate, but their results are not always consistent. ${ }^{11,18}$ Strauss et al. indicated that experimental addition of organic $\mathrm{C}$ might reduce the nitrification rates, because increased $\mathrm{C}$ availability would decrease the ability of nitrifying microorganisms to compete for $\mathrm{NH}_{4}{ }^{+}{ }^{18}$ In contrast, consistent with the findings of Dodds and Jones ${ }^{39}$ we observed that nitrification potential was positively correlated with the sediment $\mathrm{C}$ level. This positive relationship may be explained by the fact that high STC is generally associated with high STN, which is positively correlated with sediment potential nitrification. In the path analyses, STC had a negative 
Table 4 Indirect effects of catchment land uses on the sediment potential nitrification mediated by local environmental factors ${ }^{a}$

\begin{tabular}{|c|c|c|c|c|c|c|}
\hline Environmental factors & \multicolumn{2}{|c|}{ Catchment agriculture } & \multicolumn{2}{|c|}{ Catchment built-up land } & \multicolumn{2}{|c|}{ Catchment vegetation } \\
\hline TOC & 0.007 & 3.61 & 0.002 & 0.28 & -0.007 & 6.67 \\
\hline $\mathrm{TN}$ & 0.019 & 9.92 & 0.020 & 2.84 & -0.012 & 11.43 \\
\hline STC & 0.054 & 28.19 & -0.295 & 41.84 & 0.023 & 21.90 \\
\hline
\end{tabular}

${ }^{a}$ See Table 1 for the abbreviations. Indirect effects refer to the mathematical product of all of the possible paths from catchment land uses to potential nitrification via environmental factors (see Fig. 4). Contribution (\%) was calculated using the absolute values of indirect effects.

path coefficient (-0.37) to potential nitrification rate (Fig. 4), which provided an evidence to support our explanation.

Although many studies have determined the nitrification rates in lake sediments worldwide,, ,11,25 to our knowledge, no study has investigated how catchment land uses regulate sediment nitrification in lake ecosystems. As we hypothesized, the indirect effects of catchment land use on sediment potential nitrification in Yangtze lakes were more likely driven via changes in sediment properties than through changes in water quality. Arango and Tank found that mean nitrification rate was positively correlated with catchment agriculture in Michigan headwater streams. ${ }^{29}$ They speculated that this positive association was due to the fact that agricultural streams generally had high sediment $\mathrm{C}$ content, which was positively related to nitrification rates. ${ }^{29}$ In the present study, using the path analyses, we revealed that indirect influences of catchment land uses on sediment nitrification rates were mainly mediated by the STN (Table 4). In the Yangtze River basin, human activities especially urban areas have expanded dramatically in the past decades, accompanied by strong increases in nutrients $(\mathrm{C}, \mathrm{N}$ and $\mathrm{P})$ input to shallow lakes from catchments. Our findings highlight that anthropogenic activities in the catchments can have profound effects, not only on the local environments of lakes but also on the rates of $\mathrm{N}$-cycling processes.

\subsection{Nitrifying microorganisms and their role in regulating sediment nitrification}

We found that the mean abundance of AOA $\left(13.42 \times 10^{4}\right.$ copies per $g$ sediment) was approximately 10 times greater than that of AOB $\left(1.36 \times 10^{4}\right.$ copies per $g$ sediment $)$ in sediments of the Yangtze lakes. Similarly, an overwhelming dominance of AOA over $\mathrm{AOB}$ in nitrifying communities has been frequently observed in a wide range of aquatic and terrestrial ecosystems. ${ }^{23,40-42}$ In contrast, the Chao 1 richness $(9.65 \pm 8.12)$ and Shannon diversity $(1.20 \pm 0.63)$ of AOA communities were both significantly lower than those of AOB communities (19.84 \pm 13.83 and $2.73 \pm 0.76$ ) in lake sediments, which were consistent with some previous works. ${ }^{15,43}$ Compared with AOA communities, AOB communities in sediments of the Yangtze lakes were more sensitive to changes in local environmental factors especially trophic states (Tables 2 and 3). The AOB diversity and abundance were found to be significantly lower in eutrophic sites than in mesotrophic and hypertrophic sites. However, Herrmann et $a .^{44}$ found an increasing trend in the OTUs number of $\mathrm{AOA}$ and $\mathrm{AOB}$ from oligotrophic to mesotrophic lakes in Denmark. Moreover, Hou et al. ${ }^{25}$ indicated that AOA abundance decreased sharply from mesotrophic sites to eutrophic sites, while AOB abundance was greater in eutrophic sites than in mesotrophic sites in Lake Taihu and Lake Chaohu, China. These inconsistent results may suggest that the effects of water eutrophication on sediment ammonia-oxidizing communities are complex and site specific.

A number of studies have investigated the contributions of $\mathrm{AOA}$ and $\mathrm{AOB}$ communities to nitrification processes in different habitats, but their results are inconsistent. ${ }^{14,25,45-47}$ The relationships between sediment nitrification rates and nitrifier diversity and abundance can be positive, negative, or nonexistent. ${ }^{26}$ Sims et al. revealed that potential nitrification rate was positively related to both bacterial and archaeal amoA gene abundances. ${ }^{45}$ In addition, Hou et al. indicated that sediment potential nitrification rate was positively related to the АОВ diversity and abundance, but negatively correlated with AOA abundance. ${ }^{25}$ In the Yangtze lakes, sediment potential nitrification rates were not significantly related to community structure of both AOA and AOB (Fig. S2 $†$ ). This result is not surprising and can be due to two main reasons. First, the presence of nitrifying genes in sediments does not necessarily mean that such functional genes will be expressed or that the protein products of genes will function equivalently. ${ }^{26}$ Second, functional gene pools only partly contribute to the activity of nitrifying enzymes in the sediments at a given time..$^{15}$ Graham et al. proposed that studies whose primary purposes were to examine or predict the rates of $\mathrm{N}$ cycling processes might not need to determine functional gene abundance. ${ }^{48}$ Nonetheless, our results may suggest that local environmental factors rather than abundance and diversity of nitrifying microorganisms play a vital role in determining the sediment potential nitrification in Yangtze lakes.

\section{Conclusions}

In the Yangtze River basin, sediment potential nitrification rate in hypertrophic lake sites was slightly but not significantly 
higher than that in eutrophic and mesotrophic lake sites. However, abundance and diversity of AOB but not AOA were significantly influenced by lake trophic state. The potential nitrification rates were positively related to Chl-a, STC and STN contents, but not significantly correlated with nitrifying microorganisms and submerged plants. Path analyses demonstrated that the indirect effect of catchment land uses on lake sediment nitrification was largely mediated through STN. The diversity and abundance of AOA and AOB were mainly controlled by water quality and catchment land uses rather than sediment properties and submerged vegetation characteristics. Our results suggest that the responses of sediment nitrification potentials and nitrifying microorganisms to water eutrophication in Yangtze lakes are inconsistent. In addition, our findings highlight the importance of multi-scale abiotic factors, especially sediment properties, in regulating the nitrification process of lake sediments.

\section{Conflicts of interest}

The authors declare no conflict of interest.

\section{Acknowledgements}

Many thanks to Xiaoliang Jiang, Yujing Wu, Ziqian Xiong, Bei Lu, Guomin Li and Nanhua Liu for their help in the field and laboratory. This work has been funded by the National Natural Science Foundation of China (31570535 and 31400327).

\section{References}

1 V. H. Smith, Environ. Sci. Pollut. Res., 2003, 10, 126-139.

2 W. Z. Liu, Q. F. Zhang and G. H. Liu, Hydrobiologia, 2010, 644, 289-299.

3 P. M. Vitousek, J. D. Aber, R. W. Howarth, G. E. Likens, P. A. Matson, D. W. Schindler, W. H. Schlesinger and D. G. Tilman, Ecol. Appl., 1997, 7, 737-750.

4 J. M. Abell, D. Özkundakci and D. P. Hamilton, Ecosystems, 2010, 13, 966-977.

5 N. Gruber and J. N. Galloway, Nature, 2008, 451, 293-296.

6 W. Z. Liu, L. Yao, Z. X. Wang, Z. Q. Xiong and G. H. Liu, Biogeosciences, 2015, 12, 6059-6070.

7 S. P. Seitzinger, Limnol. Oceanogr., 1988, 33, 702-724.

8 R. M. Kreiling, W. B. Richardson, J. C. Cavanaugh and L. A. Bartsch, Biogeochemistry, 2011, 104, 309-324.

9 B. J. Bellinger, T. M. Jicha, L. P. Lehto, L. R. Seifert-Monson, D. W. Bolgrien, M. A. Starry, T. R. Angradi, M. S. Pearson, C. Elonen and B. H. Hill, J. Great Lakes Res., 2014, 40, 392403.

10 S. Leininger, T. Urich, M. Schloter, L. Schwark, J. Qi, G. W. Nicol, J. I. Prosser, S. C. Schuster and C. Schleper, Nature, 2006, 442, 806-809.

11 D. A. Bruesewitz, J. L. Tank and S. K. Hamilton, J. Geophys. Res.: Biogeosci., 2012, 117, 1-12.

12 L. Hou, Y. Zheng, M. Liu, J. Gong, X. Zhang, G. Yin and L. You, J. Geophys. Res.: Atmos., 2013, 118, 1237-1246.
13 M. Li, H. L. Cao, Y. G. Hong and J. D. Gu, Appl. Microbiol. Biotechnol., 2011, 89, 1243-1254.

14 S. D. Wankel, A. C. Mosier, C. M. Hansel, A. Paytan and C. A. Francis, Appl. Environ. Microbiol., 2011, 77, 269-280.

15 Y. Zheng, L. Hou, M. Liu, M. Lu, H. Zhao, G. Yin and J. Zhou, Appl. Microbiol. Biotechnol., 2013, 97, 8351-8363.

16 Y. Yang, N. Li, Q. Zhao, M. Yang, Z. Wu, S. Xie and Y. Liu, Environ. Sci. Pollut. Res., 2016, 23, 15358-15369.

17 P. M. Vitousek, S. Hättenschwiler, L. Olander and S. Allison, AMBIO A J. Hum. Environ., 2002, 31, 97-101.

18 E. A. Strauss, N. L. Mitchell and G. A. Lamberti, Can. J. Fish. Aquat. Sci., 2002, 59, 554-563.

19 Z. Luo, Z. Qiu, Q. Wei, G. Du Laing, Y. Zhao and C. Yan, J. Environ. Earth Sci., 2014, 72, 2225-2237.

20 K. J. Forshay and S. I. Dodson, Hydrobiologia, 2011, 668, 2134.

21 M. Tsiknia, V. A. Tzanakakis and N. V. Paranychianakis, Appl. Soil Ecol., 2013, 64, 104-111.

22 E. Soana and M. Bartoli, Aquat. Ecol., 2014, 48, 11-21.

23 A. E. Bernhard, Z. C. Landry, A. Blevins, J. R. de la Torre, A. E. Giblin and D. A. Stahl, Appl. Environ. Microbiol., 2010, 76, 1285-1289.

24 H. Yao, Y. Gao, G. W. Nicol, C. D. Campbell, J. I. Prosser, L. Zhang, W. Han and B. K. Singh, Appl. Environ. Microbiol., 2011, 77, 4618-4625.

25 J. Hou, C. Song, X. Cao and Y. Zhou, Water Res., 2013, 47, 2285-2296.

26 J. D. Rocca, E. K. Hall, J. T. Lennon, S. E. Evans, M. P. Waldrop, J. B. Cotner, D. R. Nemergut, E. B. Graham and M. D. Wallenstein, ISME J., 2015, 9, 1693-1699.

27 J. A. Foley, R. DeFries, G. P. Asner, C. Barford, G. Bonan, S. R. Carpenter, F. S. Chapin, M. T. Coe, G. C. Daily, H. K. Gibbs, J. H. Helkowski, T. Holloway, E. A. Howard, C. J. Kucharik, C. Monfreda, J. A. Patz, I. C. Prentice, N. Ramankutty and P. K. Snyder, Science, 2005, 309, 570-574.

28 L. L. Sass, M. A. Bozek, J. A. Hauxwell, K. Wagner and S. Knight, Aquat. Bot., 2010, 93, 1-8.

29 C. P. Arango and J. L. Tank, J. North Am. Benthol. Soc., 2008, 27, 90-107.

30 M. D. Harrison, P. M. Groffman, P. M. Mayer and S. S. Kaushal, Ecol. Eng., 2012, 38, 1-10.

31 W. Liu, Q. Zhang and G. Liu, Clean. - Soil, Air, Water, 2011, 39, 35-42.

32 J. H. Rotthauwe, K. P. Witzel and W. Liesack, Appl. Environ. Microbiol., 1997, 63, 4704-4712.

33 C. A. Francis, K. J. Roberts, J. M. Beman, A. E. Santoro and B. B. Oakley, Proc. Natl. Acad. Sci. U. S. A., 2005, 102, 14683-14688.

34 R. E. Carlson, Limnol. Oceanogr., 1977, 22, 361-369.

35 J. Chen, J. Chen, A. Liao, X. Cao, L. Chen, X. Chen, C. He, G. Han, S. Peng, M. Lu and W. Zhang, ISPRS J. Photogrammetry Remote Sens., 2015, 103, 7-27.

36 E. A. Strauss, W. B. Richardson, L. A. Bartsch, J. C. Cavanaugh, D. A. Bruesewitz, H. Imker, J. A. Heinz and D. M. Soballe, J. North Am. Benthol. Soc., 2004, 23, 1-14.

37 M. S. Booth, J. M. Stark and E. Rastetter, Ecol. Monogr., 2005, 75, 139-157. 
38 C. A. O'Sullivan, S. A. Wakelin, I. R. P. Fillery and M. M. Roper, Soil Res., 2013, 51, 240-252.

39 W. K. Dodds and R. D. Jones, Microb. Ecol., 1987, 14, 91-100.

40 D. Bru, A. Ramette, N. Saby, S. Dequiedt, L. Ranjard, C. Jolivet, D. Arrouays and L. Philippot, ISME J., 2011, 5, 532-542.

41 J. P. Shen, Z. Xu and J. Z. He, J. Soils Sediments, 2014, 14, 1023-1029.

42 X. Sun, A. Wang, L. Yang, L. Guo, Q. Chen, Z. Hu, L. Jiang and L. Xiao, J. Limnol., 2014, 73, 312-324.

43 D. Zhao, J. Zeng, W. Wan, H. Liang, R. Huang and Q. L. Wu, Curr. Microbiol., 2013, 67, 327-332.
44 M. Herrmann, A. M. Saunders and A. Schramm, Appl. Environ. Microbiol., 2009, 75, 3127-3136.

45 A. Sims, J. Horton, S. Gajaraj, S. McIntosh, R. J. Miles, R. Mueller, R. Reed and Z. Hu, Water Res., 2012, 46, 41214129.

46 H. Urakawa, W. Martens-Habbena, C. Huguet, J. R. de la Torre, A. E. Ingalls, A. H. Devol and D. A. Stahl, Limnol. Oceanogr., 2014, 59, 1321-1335.

47 J. M. Smith, A. C. Mosier and C. A. Francis, Microb. Ecol., 2015, 69, 13-24.

48 E. B. Graham, W. R. Wieder, J. W. Leff, S. R. Weintraub, A. R. Townsend, C. C. Cleveland, L. Philippot and D. R. Nemergut, Soil Biol. Biochem., 2014, 68, 279-282. 